\title{
Frequency analysis of minimum flows
}

\section{Análise de frequência de vazões mínimas}

\author{
Adelita Ramaiana Bennemann Granemann ${ }^{1}$, Miriam Rita Moro Mine ${ }^{1}$ and Eloy Kaviski \\ ${ }^{1}$ Universidade Federal do Paraná, Curitiba, PR, Brasil \\ E-mails: adelitarbg@hotmail.com (ARBG),mrmine.dhs@ufpr.br (MRMM), eloy.dhs@ufpr.br (EK)
}

Received: June 06, 2017 - Revised: December 22, 2017 - Accepted: January 19, 2018

\begin{abstract}
The study of minimum flows is increasingly important due to the relationship with ecosystem sustainability, the economy and its role as a sentinel of climate change. The aim of this paper is to contribute to the theoretical treatment of minimum extremes and, specifically, minimum flows. The method has two approaches: i) conventional; ii) asymptotic. In conventional analysis, the Weibull (W2) and Lognormal distributions of two parameters (LN2) were adjusted to the series of annual minimum flows and minimum averages of 7-day flows. In the asymptotic analysis approach two parent distributions, the distributions of all average daily flows, with power behavior for minimum flows, are investigated: i) Gamma; ii) LN2. The theory studied in this paper is applied to 11 gauged stations in the Iguaçu river basin with 48-year data series. It was concluded that the LN2 distribution presents the best fit according to the $\chi^{2}$ test. It was found that the Gamma distribution, with respect to the minimums, tends to a power function, and consequently the W2 distribution. The parameters $\mathrm{k}, \mathrm{b}$ and $\mu_{X}$, of the normalized annual minimum flow series are well-fitted to the LN2 distribution. According to both approaches, LN2 can be recommended for studies of minimum flows in the Iguaçu river basin.
\end{abstract}

Keywords: Minimum extremes distributions; Minimum flows; Extremes asymptotic analysis.

\section{RESUMO}

O estudo de vazões mínimas torna-se cada vez mais importante devido à relação com a sustentabilidade de ecossistemas, da economia e como sentinela das mudanças climáticas. O objetivo deste artigo é contribuir para o tratamento teórico sobre extremos mínimos e, especificamente, vazões mínimas. O método divide-se em duas abordagens: i) convencional; ii) assintótica. Na análise convencional foram ajustadas as distribuições de Weibull (W2) e Lognormal de dois parâmetros (LN2) às séries de vazões mínimas anuais e mínimas médias de 7 dias. Na análise assintótica duas distribuições "mãe”, distribuições de todas as vazões médias diárias, com comportamento de potência para vazões mínimas, foram investigadas: i) Gama; ii) LN2. O estudo foi aplicado a 11 estações fluviométricas da bacia hidrográfica do rio Iguaçu com 48 anos de dados. Concluiu-se que a distribuição LN2 apresentou melhor ajuste segundo o teste $\chi^{2}$. Verificou-se que a distribuição Gama, com relação aos mínimos, tende a uma função de potência, e em consequência à distribuição W2. Os parâmetros $\mathrm{k}$, b e $\mu_{\mathrm{X}}$, das vazões mínimas anuais moduladas, ajustaram-se bem à distribuição LN2. De acordo com as duas abordagens utilizadas, pode-se recomendar a LN2 para estudos de vazões mínimas na bacia hidrográfica do rio Iguaçu.

Palavras-chave: Distribuições de extremos mínimos; Vazões mínimas; Análise assintótica de extremos. 


\section{INTRODUÇÃO}

In the extreme value theory, the analysis of maxima always attracts more attention than that of minima. This is partly because, in general, the quantiles estimated for minimum flows are not as extreme as for maximum flows. For a large number of applications, the minimum annual flow of 7 days duration and 10-year recurrence or an estimation of the flow of $95 \%$ of permanence are sufficient. These quantiles can be estimated directly from the empirical distribution, without resorting to a theoretical model adjustment. On the other hand, really severe droughts, such as occurred exceptionally during the rainy season of the 2014 hydrological year (Oct/2013 to March/2014) in the Southeast region of Brazil, where the estimated return period was over 100 years, according to Nakayama et al. (2015), require the application of theoretical statistical models that present a good fit to the hydrological variables under study.

There are still many details to be discovered and clarified for the distribution function properties of minima. Increasing recognition of the importance of minimum flows for ecosystem viability, economic sustainability and as a climate change alert, makes the study of small extreme minima more and more important (GOTTSCHALK et al., 2013).

In this context, the study of minimum flow is necessary, because these are the parameters for granting water use and dilution of effluents that influence the management of conflicts through use in situations of scarcity. Understanding the characteristics of minimum flow formation is crucial for the efficient development and integrated management of these water resources. It is important to raise the question: how to postulate an adequate distribution that respects the principle of parsimony (few parameters) to describe the phenomenon of interest?

Bibliographical research showed the frequent use of the Lognormal distribution of two parameters(LN2) as a model for minimum flows, verified in the studies of Silvino et al. (2007), Uliana et al. (2011), Correa and Melo (2014), Victorino et al. (2014) and Finkler et al. (2015). For this reason, it is important to verify if this really is the best distribution to be considered, since its asymmetry is positive. This work proposes to analyze in detail the distributions of Weibull, Lognormal of two parameters and Gamma, with respect to the study of frequency of minimum extremes. Since most advanced statistical books deeply discuss recommended distributions to maximum extremes with real examples, but for minimum events distributions area described in a few paragraphs, merely saying that the adjustment procedures are similar

The objective is to extend the theoretical treatment on minimum extremes and specifically minimum flows. Two approaches are considered: i) conventional frequency analysis; ii) asymptotic analysis of minimum extremes (Block Method). Therefore, this work was applied to 11 fluviometric stations in the Iguaçu river basin with data series of 48 years. The adjustment of distribution W2 and LN2 was verified at minimum annual flow and minimum moving average of 7 days duration. It was also analyzed whether the power behavior of the distribution of the mean daily flows (parent distribution), here postulated as Gamma and LN2, towards the minimum values (tail distribution) corresponds to a W2 distribution (Weibull attraction domain).

\section{FREQUENCY ANALYSIS OF MINIMUM FLOW}

The flow of a river is the result of natural processes operating on a river basin scale. Conceptually, the basin can be understood as a series of interconnected reservoirs, each of them with recharge, storage and discharge components (SMAKHTIN, 2001). The drought period is governed by the underground contribution in the absence of precipitation. The minimum flow regime results from natural factors, including hydraulic characteristics and extension of aquifers, geology, relief, soil infiltration characteristics, frequency and quantity of recharge, evapotranspiration rates, precipitation, temperature, seasonal variation, vegetation types, topography, climate, as well as anthropogenic factors (KAVISKI, 1983; BANGASH et al., 2012).

It is important to study the behavior of this hydrological variable, since this knowledge enables the determination of adequate reference values for water availability in a certain region. Knowledge of water availability is the basic information for decision making in in water resources management (MELLO et al., 2010; MOREIRA; SILVA, 2014; VICTORINO et al., 2014).

The analysis of minimum flows is similar to the analysis of maximum flows, except for the fact that in the case of minimum flows, the interest is due to the probability of occurrence of flows equal to or lower than a certain limit. To find this flow value, we use probability distributions that best fit the observed flows (ULIANA et al., 2011).

The true distributions of probabilities of minimum flows are unknown and the practical problem is to identify a reasonable functional distribution (called here a postulated distribution) and quantify its parameters (SMAKHTIN, 2001).

Currently, extreme value theory is an important and active branch of statistics, with highly relevant practical developments, mainly in the fields of economics and engineering (NAGHETTINI; PINTO, 2007).

It is not possible to assume a definition of the probability distribution to describe the frequency of flows in hydrology but rather, to select a family of curves indicated for the type of data analyzed and then to individualize the probability law that best adapts to interpreting each available historical series. Among the distribution functions most frequently referenced in the literature related to minimum flows are the following: Asymptotic Distributions of Extremes, including Type I (Gumbel Distribution for Minima) and Type III (Weibull Distribution), Pearson Type III and Lognormal of two and three parameters (EUCLYDES, 1992; SILVA et al., 2006; NAGHET'TINI; VON SPERLING, 2014).

Book authors working on extreme value theory, such as Coles (2001) and others, develop the theory of maxima from a sequence of random variables $X_{i}$ in detail, whereas for minimum events the subject is covered by saying that the same procedures are applied to the identity $\min \left\{X_{1}, X_{2}, \ldots, X_{v}\right\}=-\max \left\{-X_{1},-X_{2}, \ldots,-X_{v}\right\}$.

Gottschalk et al. (2013) present the study of extreme values for minima, this theory is not often found in books. It is possible to understand, with an in-depth study, the entire spectrum of the tail behavior problem of the parent distribution (distribution of the original series) via the asymptotic theory of the extreme values for approximate distributions, still allowing the physical interpretation of the parameters. This opens a wide line of research for the joint 
and consistent analysis of the physics problem with its stochastic nature, in other words, the behavior of minimum daily flows.

According to the block method (BM - Block Method), presented by Gottschalk et al. (2013), the power $k$ (shape parameter) of the Weibull distribution, which defines its shape, is derived from the parent distribution by the tail behavior toward the minimum extremes. There is also an identification between the power behavior of the parent distribution for minimum flows with the exponential behavior of the recession curve. Also, according to the authors mentioned in this paragraph, the BM method presents a second parameter, effective number of independent observations $(v)$. It is also possible to determine the general dependence of this parameter on the coefficient of variation of the parent distribution.

A review of the subject was performed and thus it was observed in Silva (2003) that extreme events do not follow a Normal distribution, they are more adapted to the generalized distribution of extreme values (GEV). According to Kaviski (1983), the probability distributions that are usually considered satisfactory models when applied to series of minimum flows are: Lognormal of three parameters (Galton), extremes type I, applied to the logarithm of events (LogGumbel), and extremes type III (Weibull).

For Tomaz (2013) the observation that, in an extreme scenario, the flows through a river section are necessarily zero lower bounded, makes the Weibull distribution a natural candidate for the modeling of minimum hydrological events.

Clarke (1993) also observed that the distribution that presented the highest adhesion to minimum flows was the Weibull distribution. Mamun et al. (2010) tested several distributions and found that, in general, the distribution of extreme values (GEV) showed good adjustment for most of the minimum flows.

Euclydes (1992) and Silva et al. (2006) found better representation with the three-parameter Lognormal probability model. And Uliana et al. (2011) state that the Lognormal distribution is adequate for the determination of $\mathrm{Q}_{7,10}$.

The Weibull distribution is highly recommended as a good model for the frequency analysis of the minimum flows. The studies analyzed indicate that the most indicated frequency distribution varies by region, and there is not only one frequency distribution clearly superior to all others.

\section{METHODS}

The method is divided into two approaches, conventional analysis and asymptotic analysis. The conventional analysis developed with the adjustment of the Weibull (W2) and Lognormal two parameter (LN2) distributions to data of 11 series of minimum annual flows and minimum moving average flows of 7 days, and with the conventional estimation of parameters. The adjustments are analyzed by Kolmogorov-Smirnov (KS) and Chi-Square $\left(\chi^{2}\right)$ adhesion tests. The asymptotic analysis was based on the Gottschalk et al. (2013) paper, and in this research emphasis is given to the Block Method (BM). This is based on the theory of extreme values, in which the adjustment of the parent distributions (defined here as the original series distributions and that present power behavior for low values) Gamma and LN2 to data series of daily average flows, and the left tail tendency to the Weibull distribution described by power law is verified. In this approach, the Weibull distribution parameters are determined as a function of the coefficient of variation of the "mother" distributions. The results are analyzed graphically.

\section{Conventional analysis}

The study is applied to annual series of minimum moving average flows of 7 days and minimum annual flows. Two distributions were selected: i) Lognormal of two parameters (LN2); ii) Weibull (W2). The LN2 distribution is recommended in the literature for annual maximum flow due to its always positive asymmetry, but also for annual minimum flows, considering that it is limited inferiorly to positive random variables, the case of average annual minimum daily flows.

The probability density function (PDF) of the LN2 distribution is given by Equation 1 (GOTTSCHALK et al., 2013), where $X$ is the random variable of minimum moving average of 7 days duration (or minimum annual flow), where $Y$ is its logarithm. The two first moments of the flow logarithms are represented respectively by $\mu_{Y}$, and $\sigma_{Y}$, according to Equations 2 and 3 , called natural parameters of the distribution estimated by the method of moments (STEDINGER et al., 1992):

$$
\begin{aligned}
& f_{X}(x)=\frac{1}{x \sqrt{2 \pi \sigma_{Y}^{2}}} \exp \left[-\frac{1}{2}\left(\frac{\ln x-\mu_{Y}}{\sigma_{Y}}\right)^{2}\right] \text { para } x>0 \\
& \mu_{Y}=\ln \left(\mu_{X}\right)-\frac{1}{2} \sigma_{Y}^{2} \\
& \sigma_{Y}=\left[\ln \left(1+\frac{\sigma_{X}^{2}}{\mu_{X}^{2}}\right)\right]^{1 / 2}
\end{aligned}
$$

The cumulative distribution function (CDF) of the W2 distribution is presented in Equation 4, where Weibull included a lower bound parameter $u$ and a scale parameter $b$ beyond the form parameter $k$. The random variable $X$ represents the minimum annual flow (or minimum moving average of 7 days duration). To estimate the parameters, we use Equations 5 and 6:

$$
F_{X}(x)=1-\exp \left\{-\left(\frac{x-u}{b}\right)^{1 / k}\right\} u \leq x \leq \infty ; x>0 ; b k>0
$$

$\mu_{X}=b \Gamma(1+k)$

$\sigma_{X}=b\left[\Gamma(1+2 k)-\Gamma^{2}(11+k)\right]^{1 / 2}$

In Equation 4, the variable $x$ grows from its minimum $u$ to infinity. In the case of daily average flows, parameter $u$ is considered equal to zero.

The performance of the distributions in the conventional analysis was verified based on the Kolmogorov-Smirnov (KS) and Chi-Square $\left(\chi^{2}\right)$ adhesion tests. These are among the tests cited by Naghettini and Pinto (2007) as the main adhesion tests applied in the context of statistical hydrology. According to Silvino et al. (2007), the KS and $\chi^{2}$ tests are the most commonly used and most appropriate for continuous random variables such as flow rates. 
The $\chi^{2}$ test analyzes whether the occurrence frequencies of the data separated into $k$ equiprobable class intervals, which were defined from the analyzed distribution, are in agreement with the frequencies expected for these intervals. The present study considered the $95 \%$ confidence interval and a degree of freedom equal to the number of classes minus 2. (GOMIDE, 1976).

The KS test principle is the maximum difference between the empirical and theoretical cumulative probability function of continuous random variables. This is a non-parametric test, and it is applicable only to test the fit adequacy of the fully specified continuous distributions, that is, when there are no parameters to be estimated. Then the studied series was divided into two parts, the first used to adjust the distribution and determine the parameters and determination of the parameters, and the second to apply the KS adhesion test (GOMIDE, 1976). The null hypothesis to be tested is $H_{0}: P(X<x)=F_{X}(x)$. The level of significance $(\alpha)$ was considered equal to $5 \%$.

\section{Asymptotic analysis}

Weibull's minimal domain of attraction (Type III Extreme Distribution) contains limited distributions toward the minimum. Examples are the Uniform and Beta distributions when they are limited toward the minimum as well as the maximum. Consequently, distributions with power law behavior close to the lower limit belong to this domain of attraction. Therefore, one can write the Equation 7:

$$
F_{X}(x) \cong C(x-u)^{1 / k}
$$

For constants $C>0$ and $k>0, F_{X}(x)$ converges when $x \rightarrow u$ to the Weibull distribution with constant $b_{v}=(C v)^{-k}$, where $v$ is the number of block elements (GOTTSCHALK et al., 2013).

The Lognormal, Gamma, and Exponential distributions all have a power law behavior close to their lower limit that is equal to zero in all cases. The behavior close to zero of the Gamma and Lognormal distributions was analyzed. They are considered parent distributions for the average daily flows that are normalized with respect to the long term average, that is, the random variable $X$ (average daily flow) to be studied here has a mean $\mu_{X}=1$ and standard deviation equal to the coefficient of variation $V_{X}$.

The BM theory points to the possibility of a dependence between the parameters of the minimum distribution and the coefficient of variation of the parent distribution, which is tested in the available data.

According to Gottschalk et al. (2013), from the PDF of the Gamma distribution, the CDF can be deduced for the case of normalized variables, which can be expressed only in terms of the coefficient of variation given by Equation 8:

$$
f_{X}(x)=\frac{1}{V_{X}^{2 V_{X}^{-2}} \Gamma\left(V_{X}^{-2}\right)} x^{V_{X}^{-1}-1} e^{-x V_{X}^{-2}} \quad x>0
$$

The integral of Expression 8 can not be obtained analytically, but by numerical approximations. The Excel DISTGAMA function was used to calculate the CDF.
Adopting as the parent distribution the Gamma distribution and considering minimum values with respect to the equivalent tail between the power law (Equation 7) and the parent distribution postulated Gama, using the l'Hôpital rule to determine the limits, we arrive at the values of the Constants 9 and 10, respectively:

$$
\begin{aligned}
& k=V_{X}^{2} \\
& C=\left\{V_{X}^{2 V_{X}^{-2}} \Gamma\left(V_{X}^{-2}+1\right)\right\}^{-1}
\end{aligned}
$$

The constant $b_{v}>0$, in the case of the Gamma distribution is given by Equation 11:

$$
b_{v}=V_{X}^{2}\left\{\frac{\Gamma\left(V_{X}^{-2}+1\right)}{v}\right\}^{V_{X}^{2}}
$$

According to Gottschalk et al. (2013), the LN2 distribution can also be expressed in terms of the coefficient of variation only for normalized variables. The PDF is given by Equation 12 below:

$$
f_{X}(x)=\frac{1}{x \sqrt{2 \pi \ln \left(1+V_{X}^{2}\right)}} \exp \left\{-\frac{1}{2} \frac{\left(\ln (x)+\frac{1}{2} \ln \left(1+V_{X}^{2}\right)\right)^{2}}{\ln \left(1+V_{X}^{2}\right)}\right\} ; 0<x<\infty
$$

The Excel DIST.LOGNORMAL.N function can be used to calculate the probabilities for the normalized variable.

The values of $k$ and $C$ of Equation 7 will depend on the probabilities for which the power behavior adjustment was selected. The equations for $k$ and $C$ are given by Equations 13 and 14 .

$$
\begin{aligned}
& k=a_{k} \sqrt{\ln \left(1+V_{X}^{2}\right)} \\
& C=a_{c} V_{X}^{p_{C}}
\end{aligned}
$$

where $a_{k}, a_{c}$ and $p_{C}$ are tuning parameters, which were obtained for several levels of probability $\alpha$ from the work of Gottschalk et al. (2013) using the probability level $\alpha=0.01$. For this study the value of interest is $\alpha=0.1$ corresponding to the return period of 10 years. The values of the parameters for different levels of probability are presented in Table 1 . The constant $b_{v}$ is given by Equation 15:

$$
b_{v}=\left(a_{c} V_{X}^{p_{c}} v\right)^{-a_{k} \sqrt{\ln \left(1+V_{X}^{2}\right)}}
$$

Table 1. Values of $a_{k}, a_{c}$ and $p_{C}$ for different probability levels $\alpha$.

\begin{tabular}{cccc}
\hline $\boldsymbol{\alpha}$ & $\boldsymbol{a}_{\boldsymbol{k}}$ & $\boldsymbol{a}_{\boldsymbol{c}}$ & $\boldsymbol{p}_{\boldsymbol{c}}$ \\
\hline 0.001 & 0.3195 & 59.8159 & 0.9350 \\
0.002 & 0.3366 & 36.4476 & 0.8875 \\
0.005 & 0.3651 & 18.5459 & 0.8184 \\
0.010 & 0.3929 & 10.9772 & 0.7604 \\
0.020 & 0.4291 & 6.4447 & 0.6963 \\
0.050 & 0.4984 & 3.1774 & 0.5995 \\
0.100 & 0.5812 & 1.8807 & 0.5140 \\
0.200 & 0.7231 & 1.1498 & 0.4131 \\
0.500 & 1.2543 & 0.6991 & 0.2382 \\
\hline
\end{tabular}


In the case of the asymptotic analysis (BM Method), the evaluation of the probability distributions was performed from a graphical analysis of the parameters comparing the Weibull distribution parameters with the coefficient of variation of the parent distribution.

The near zero behavior of the Gamma and Lognormal distributions was analyzed for a range of coefficients of variation $V_{X}$ from 0.5 to 2.5 . For the observed $V_{X}$ the distributions were compared with the power function of the attractiveness domain of the Weibull distribution.

In order to verify the relationship of $V_{X}$ and the asymmetry coefficient $\gamma$, the moment diagram was constructed, in which the coefficient of variation and the asymmetry coefficient are calculated according to Equations 16 and 17, respectively, for series of daily average flows. In order to analyze the dispersion of the points around the curve we also obtained the theoretical Weibull curve.

$V_{X}=\sigma_{X} / \mu_{X}$

$\gamma=\frac{N}{(N-1)(N-2)} \frac{\sum_{i=I}^{N}\left(x_{i}-\bar{x}\right)^{3}}{s^{3}}$

The theoretical relation of the $V_{X}$ of the parent distribution with the parameters of the Weibull distribution $k$ and $b$, as well as the first and second moments, $\mu$ and $\sigma$, were analyzed through graphs with the theoretical curves of the investigated distributions, Gamma and Lognormal. According to Gottschalk et al. (2013) the parameters $k, b, \mu$ and $\sigma$ are estimated using the moments method.

\section{CASE STUDY}

The case study was applied to the basin of the Iguaçu River, a tributary of the Paraná River, the largest river in the State of Paraná. On the border of Curitiba with the cities of Pinhais and São José dos Pinhais, the Iraí and Atuba rivers meet, forming the Iguaçu River. The river course follows the general direction from east to west with some parts serving as a natural boundary between Paraná and Santa Catarina, and in a certain stretch of its low course it is the border between Brazil and Argentina (province of Misiones).

For the present work, 11 fluviometric stations (ANA, 2014) were selected from the Iguaçu river basin, whose location is shown in Figure 1, along with the secondary stations, with which multiple faults were filled by linear regression. The largest continuous and common periods of observation of the flows in the secondary and main stations were considered for the formulation of the regression equations. Several equations were obtained and the criterion used was to apply only those that resulted in a high coefficient of determination.

The criteria for selection were: stations that are not affected by reservoirs with a high level of regularization, that is, stations in the Iguaçu River upstream of Porto Vitoria and its tributaries; minimum observation period of 30 years; data consistency level of 2 (ANA, 2014); without failures of consecutive years or consecutive months for each year; stations that form a set with the maximum common period of observations; filling of faults that results in flows with a coherent magnitude; and good spatial distribution in the river basin.

The main stations are: Porto Amazonas (PA - 65035000), São Mateus do Sul (SM - 65060000), Rio Negro (RN - 65100000), Rio da Várzea dos Lima (VL - 65135000), São Bento (SB - 65155000), (UV - 65310000), Jangada do Sul (JS - 65370000), Fazenda Maracanã (FM - 65415000), Santa Clara (SC - 65825000), Ponte do Vitorino (PV - 65945000) and Águas do Verê (AV - 65960000). The common observation period is 48 years from 1957 to 2004. The secondary stations are: Fragosos (FR-65090000), Rio Preto do Sul (RP-65095000), Quitandinha (Q-65136550), Fluviópolis (F-65220000) and Santana ferry (BS - 65955000). Only PA, UV and SC stations did not show any failures in the defined period.

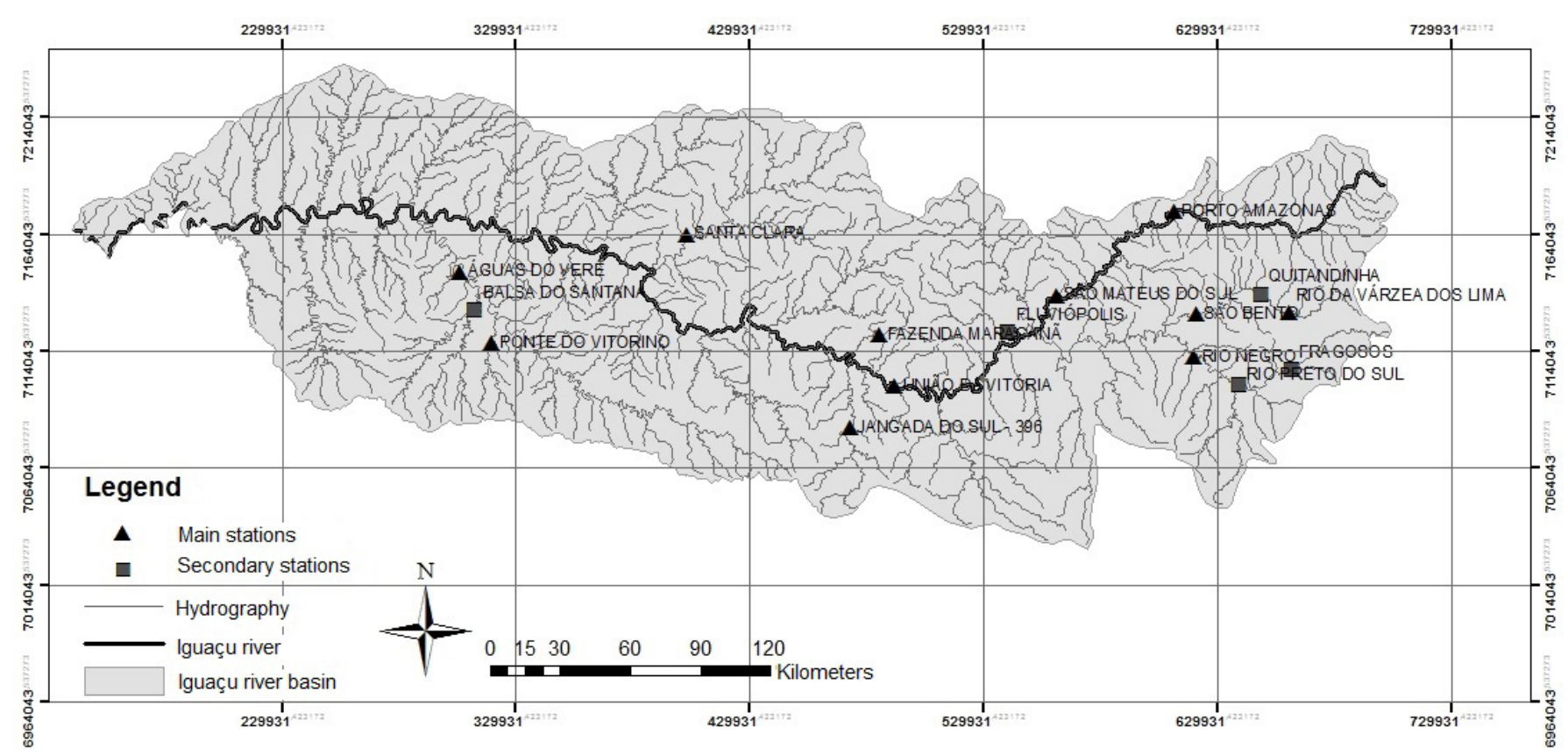

Figure 1. Iguaçu river basin and fluviometric stations of the study. 


\section{RESULTS AND DISCUSSION}

\section{Conventional analysis}

Tables 2 and 3 present the 10 -year return period quantiles for the LN2 and W2 probability distributions. The W2 distribution resulted in the lowest flow values for most of the analyzed stations (except AV and PV for annual minimums, but even values were close),

Table 2. Minimum moving average of 7 days flow and return period of 10 years in $\mathrm{m}^{3} / \mathrm{s}$.

\begin{tabular}{ccrr}
\hline Station & Empirical & LN2 & W2 \\
\hline PA & 5.40 & 5.98 & 5.07 \\
UV & 66.26 & 66.55 & 53.85 \\
SC & 10.41 & 11.28 & 9.94 \\
SB & 7.17 & 7.34 & 6.40 \\
AV & 16.33 & 14.97 & 14.54 \\
SM & 14.80 & 15.10 & 12.50 \\
PV & 1.37 & 1.37 & 1.33 \\
RN & 13.33 & 13.53 & 11.66 \\
VL & 2.79 & 2.58 & 2.21 \\
JS & 2.18 & 2.38 & 1.83 \\
FM & 0.86 & 0.90 & 0.71
\end{tabular}

Table 3. Minimum annual flows for return period of 10 years in $\mathrm{m}^{3} / \mathrm{s}$.

\begin{tabular}{ccrr}
\hline Station & Empirical & LN2 & W2 \\
\hline PA & 4.29 & 5.00 & 4.07 \\
UV & 61.94 & 62.54 & 51.39 \\
SC & 9.51 & 10.39 & 9.28 \\
SB & 6.66 & 6.93 & 6.02 \\
AV & 14.17 & 13.32 & 13.52 \\
SM & 13.40 & 14.17 & 11.57 \\
PV & 1.16 & 0.80 & 1.11 \\
RN & 12.40 & 12.44 & 10.60 \\
VL & 2.54 & 2.38 & 1.99 \\
JS & 1.65 & 1.82 & 1.45 \\
FM & 0.66 & 0.76 & 0.63 \\
\hline
\end{tabular}
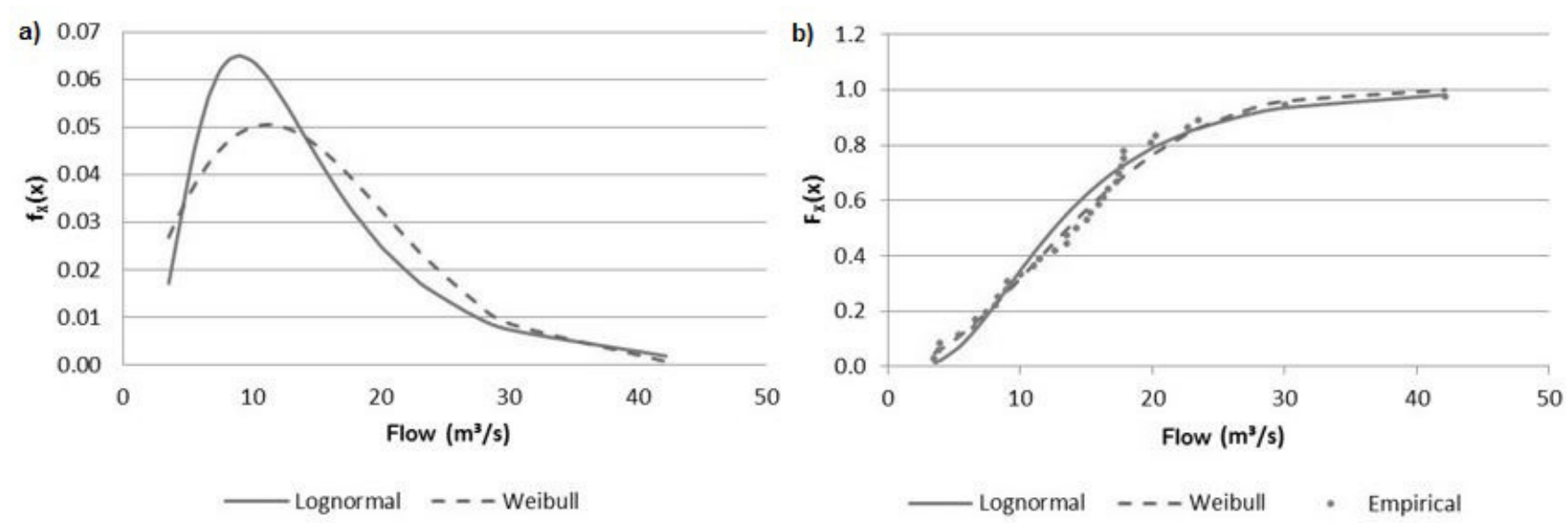

Figure 2. (a) PDF and (b) CDF to Porto Amazonas for 7-day minimum moving average.

followed by Empirical and LN2 distribution with higher values. Except for the AV, PV and VL stations, this relation was different, and Empirical generated the highest flow values. These results are within the expected range, since the samples are not large enough for the sample value to reach the theoretical value.

Figures 2 and 3 present the PDF and CDF of the LN2 and W2 distributions adjusted to the PA and VL stations, respectively, for the minimum flows of 7 days. The CDF is presented along with the sample values of the empirical distribution.

The evaluation of the adjustment adequacy of the studied distributions through the KS and $\chi^{2}$ adhesion tests is shown in Tables 4 and 5, respectively. For the KS test the flow series were divided into two parts, the first containing the years 1957 to 1991, and the second, for which the KS test was applied, comprises the years 1992 to 2004 . The $\chi^{2}$ test was applied to the total period from 1957 to 2004. The significance index considered for the tests was $5 \%$, and the null hypotheses $H_{0}$ to be tested were: the series of minimum flows studied follows a distribution: i) W2, to test the distribution W2; ii) LN2, to test the LN2 distribution.

It was possible to verify that the LN2 distribution had a greater number of acceptances by the $\chi^{2}$ test, but the same did not happen with the KS test, since only the PV station had rejection of the null hypothesis when analyzing the annual minimum flows. For the Weibull distribution, there was also a divergence between the results of the $\chi^{2}$ and KS tests. The PA, SC, SB, AV, $\mathrm{PV}$, JS and FM stations had a good fit to the Weibull distribution by the $\chi^{2}$ test, and for the KS test the result was the opposite. A more conservative KS test result was expected when applied to the sample different from that used for parameter estimation.

The application of the $\chi^{2}$ and KS tests showed exactly opposite results for almost all the stations and for the two distributions investigated. It is possible to observe that the LN2 distribution generated values closer to the empirical distribution and presented a better adjustment according to the $\chi^{2}$ test in almost all the stations, and the null hypothesis was rejected only in the PV station. With the KS test the LN2 distribution obtained a good adjustment only in the UV station. 

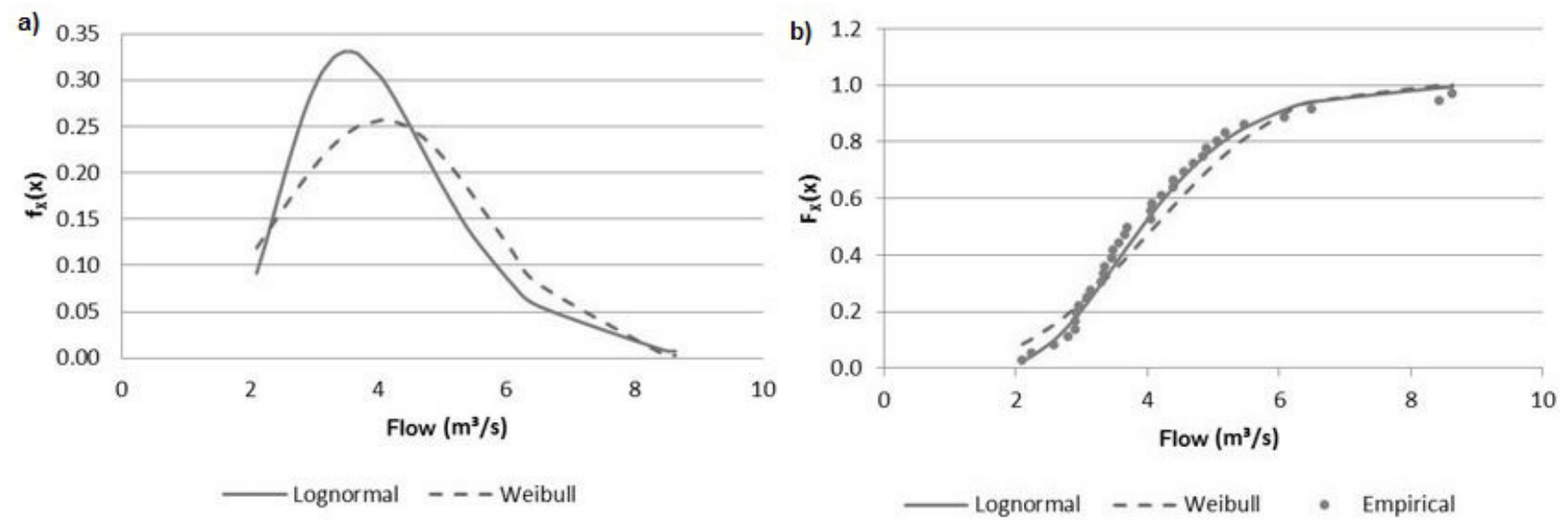

Figure 3. (a) PDF and (b) CDF to Rio da Várzea dos Lima for 7-day minimum moving average.

Table 4. Adhesion tests KS and $\chi^{2}$ for minimum moving average daily flow of 7 days.

\begin{tabular}{|c|c|c|c|c|c|c|c|c|c|c|c|c|}
\hline \multirow{3}{*}{ 苛 } & \multicolumn{6}{|c|}{ Lognormal Distribution } & \multicolumn{6}{|c|}{ Weibull Distribution } \\
\hline & \multicolumn{3}{|c|}{$x^{2}$} & \multicolumn{3}{|c|}{ KS } & \multicolumn{3}{|c|}{$\chi^{2}$} & \multicolumn{3}{|c|}{ KS } \\
\hline & $D_{1 \text { calc }}$ & $D_{1 \text { tab }}$ & $\begin{array}{c}\text { Hypothesis } \\
H_{o}\end{array}$ & $D_{2 \text { calc }}$ & $D_{2 t a b}$ & $\begin{array}{c}\text { Hypothesis } \\
H_{o}\end{array}$ & $D_{1 \text { calc. }}$ & $D_{1 t a b}$ & $\begin{array}{c}\text { Hypothesis } \\
H_{o}\end{array}$ & $D_{2 \text { calc. }}$ & $D_{2 t a b}$ & $\begin{array}{c}\text { Hypothesis } \\
H_{o}\end{array}$ \\
\hline $\mathrm{PA}$ & 2.20 & 7.81 & Accepted & 0.41 & 0.23 & Rejected & 5.15 & 7.81 & Accepted & 0.36 & 0.23 & Rejected \\
\hline UV & 6.01 & 9.49 & Accepted & 0.19 & 0.23 & Accepted & 13.18 & 9.49 & Rejected & 0.21 & 0.23 & Accepted \\
\hline SC & 2.35 & 7.81 & Accepted & 0.39 & 0.23 & Rejected & 3.29 & 7.81 & Accepted & 0.33 & 0.23 & Rejected \\
\hline SB & 3.65 & 9.49 & Accepted & 0.29 & 0.23 & Rejected & 6.76 & 9.49 & Accepted & 0.27 & 0.23 & Rejected \\
\hline AV & 2.12 & 9.49 & Accepted & 0.38 & 0.23 & Rejected & 3.90 & 9.49 & Accepted & 0.31 & 0.23 & Rejected \\
\hline SM & 2.93 & 7.81 & Accepted & 0.40 & 0.23 & Rejected & 10.19 & 7.81 & Rejected & 0.36 & 0.23 & Rejected \\
\hline PV & 5.45 & 7.81 & Accepted & 0.46 & 0.23 & Rejected & 3.99 & 7.81 & Accepted & 0.39 & 0.23 & Rejected \\
\hline $\mathrm{RN}$ & 3.68 & 7.81 & Accepted & 0.23 & 0.23 & Accepted & 10.10 & 7.81 & Rejected & 0.17 & 0.23 & Accepted \\
\hline VL & 5.38 & 9.49 & Accepted & 0.36 & 0.23 & Rejected & 22.14 & 9.49 & Rejected & 0.31 & 0.23 & Rejected \\
\hline JS & 2.48 & 7.81 & Accepted & 0.34 & 0.23 & Rejected & 6.90 & 7.81 & Accepted & 0.31 & 0.23 & Rejected \\
\hline $\mathrm{FM}$ & 5.15 & 7.81 & Accepted & 0.31 & 0.23 & Rejected & 7.34 & 7.81 & Accepted & 0.29 & 0.23 & Rejected \\
\hline
\end{tabular}

Table 5. Adhesion tests KS and $\chi^{2}$ for minimum flow.

\begin{tabular}{|c|c|c|c|c|c|c|c|c|c|c|c|c|}
\hline \multirow{3}{*}{ 苞 } & \multicolumn{6}{|c|}{ Lognormal Distribution } & \multicolumn{6}{|c|}{ Weibull Distribution } \\
\hline & \multicolumn{3}{|c|}{$\chi^{2}$} & \multicolumn{3}{|c|}{ KS } & \multicolumn{3}{|c|}{$\chi^{2}$} & \multicolumn{3}{|c|}{ KS } \\
\hline & $D_{1 \text { calc }}$ & $D_{1 t a b}$ & $\begin{array}{c}\text { Hypothesis } \\
H_{o} \\
\end{array}$ & $D_{2 \text { calc }}$ & $D_{2 t a b}$ & $\begin{array}{c}\text { Hypothesis } \\
H_{o}\end{array}$ & $D_{1 \text { calc. }}$ & $D_{1 t a b}$ & $\begin{array}{c}\text { Hypothesis } \\
H_{o}\end{array}$ & $D_{\text {2calc. }}$ & $D_{2 t a b}$ & $\begin{array}{c}\text { Hypothesis } \\
H_{o}\end{array}$ \\
\hline $\mathrm{PA}$ & 0.61 & 7.81 & Accepted & 0.40 & 0.23 & Rejected & 2.50 & 7.81 & Accepted & 0.36 & 0.23 & Rejected \\
\hline UV & 4.24 & 5.99 & Accepted & 0.22 & 0.23 & Accepted & 7.62 & 5.99 & Rejected & 0.23 & 0.23 & Accepted \\
\hline SC & 1.10 & 7.81 & Accepted & 0.44 & 0.23 & Rejected & 3.16 & 7.81 & Accepted & 0.38 & 0.23 & Rejected \\
\hline SB & 3.63 & 9.49 & Accepted & 0.29 & 0.23 & Rejected & 8.69 & 9.49 & Accepted & 0.26 & 0.23 & Rejected \\
\hline AV & 4.15 & 9.49 & Accepted & 0.41 & 0.23 & Rejected & 3.39 & 9.49 & Accepted & 0.34 & 0.23 & Rejected \\
\hline SM & 4.69 & 7.81 & Accepted & 0.39 & 0.23 & Rejected & 13.41 & 7.81 & Rejected & 0.36 & 0.23 & Rejected \\
\hline PV & 8.86 & 7.81 & Rejected & 0.50 & 0.23 & Rejected & 0.58 & 7.81 & Accepted & 0.47 & 0.23 & Rejected \\
\hline $\mathrm{RN}$ & 4.98 & 7.81 & Accepted & 0.24 & 0.23 & Rejected & 17.03 & 7.81 & Rejected & 0.18 & 0.23 & Accepted \\
\hline VL & 7.24 & 9.49 & Accepted & 0.40 & 0.23 & Rejected & 22.88 & 9.49 & Rejected & 0.34 & 0.23 & Rejected \\
\hline JS & 3.02 & 7.81 & Accepted & 0.30 & 0.23 & Rejected & 7.29 & 7.81 & Accepted & 0.25 & 0.23 & Rejected \\
\hline FM & 2.98 & 7.81 & Accepted & 0.31 & 0.23 & Rejected & 4.31 & 7.81 & Accepted & 0.27 & 0.23 & Rejected \\
\hline
\end{tabular}


For the W2 distribution, the PA, SC, SB, AV, PV, JS and FM stations had a good fit to the Weibull distribution by the $\chi^{2}$ test. And for the KS test, the same stations, including SM and VL, did not show a good fit

\section{Asymptotic analysis}

Figures $4 \mathrm{a}$ and $5 \mathrm{a}$ illustrate the integral of the Gamma distribution (8) on a bilogarithmic scale for coefficients of variation from 0.5 to 2.5 , for PA and UV stations, respectively. The graphs confirm the near-zero power law behavior of this distribution. For coefficients of variation less than 0.5 , the power behavior occurs only for very small probabilities, while for larger values of $V_{X}$ the approximation is valid for larger probabilities.

Figure $4 \mathrm{~b}$ adds a power function, given by Equation 11 for observed $V_{X}$ from each station, in this case PA. This figure shows that the Gamma distribution, with respect to the minimums, tends exactly to the power distribution and, consequently, to the Weibull distribution, in the direction of the tail equivalent to the minimums. The same is true for the UV station, in Figure 5b, as well as for the other stations. Thus it is concluded that the Gamma distribution is the parent distribution that most closely approximates the power function of the attractiveness domain of the Weibull distribution.

Figures 6 and 7 illustrate the Lognormal distribution for normalized variables (mean of 1.0 and standard deviation equal to the coefficient of variation) on a bilogarithmic scale for several coefficients of variation, and only for the coefficient of variation observed for each station with the approximation of the power function. By analyzing these figures it can be anticipated that the power behavior is not as accurate as for the Gamma distribution.

The hypothesis of Gottschalk et al. (2013), that the lower tail of the Lognormal distribution tends to the power function only for specified levels of probability, was not verified integrally for the Iguaçu river basin. For the level of probability 0.1 this hypothesis was confirmed for the stations UV, SC, SB, AV, RN and VL. For PA and SM (Figure 6) it was found that there is a good approximation between the tail of the Lognormal and the
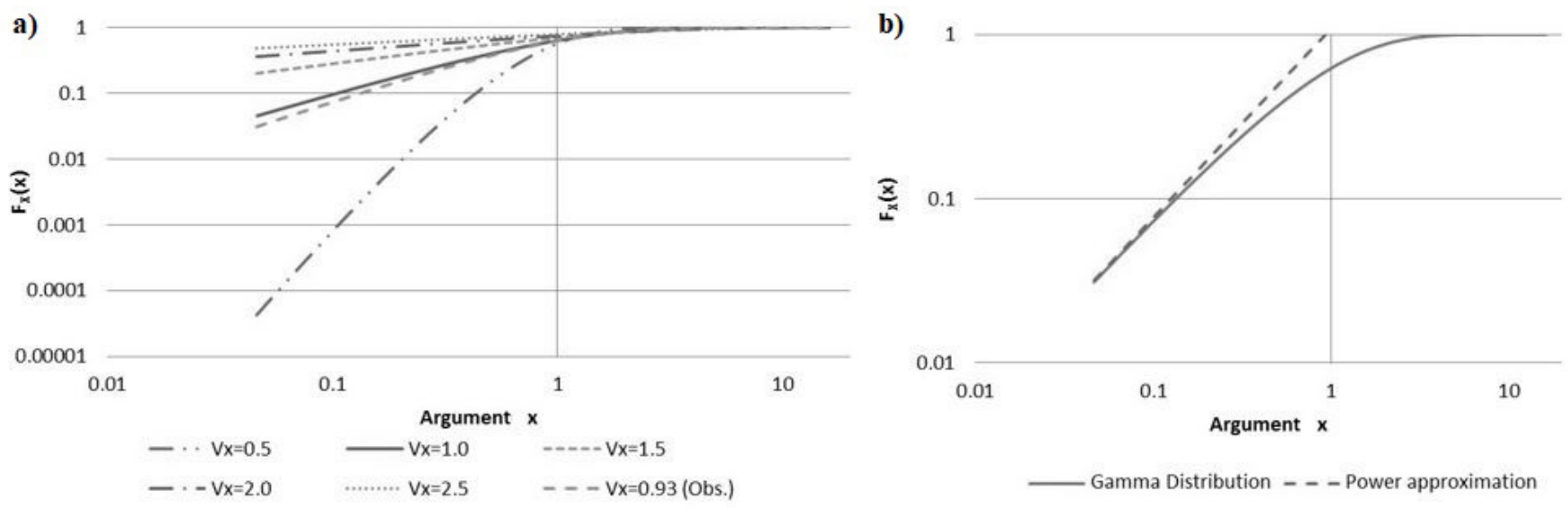

Figure 4. Gamma distribution normalized in bilogarithmic scale for different values of $V_{X}$ (a) with the approximation of the power function (b) for the Porto Amazonas station.
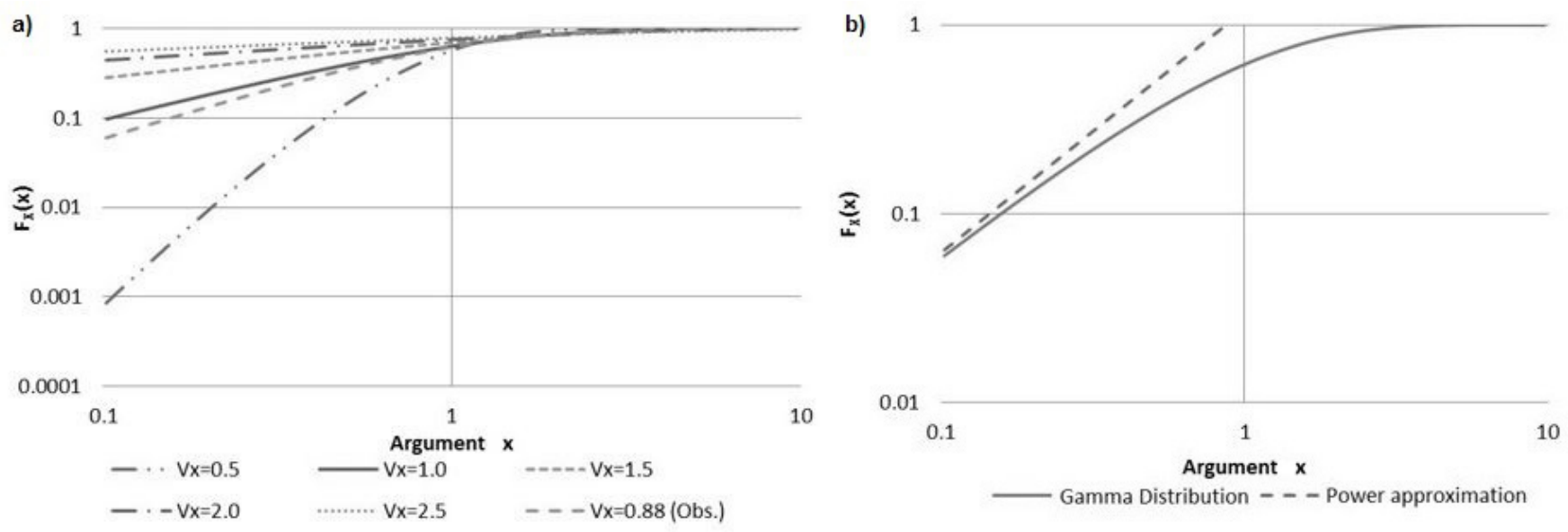

Figure 5. Gamma distribution normalized in bilogarithmic scale for different values of $V_{X}$ (a) with the approximation of the power function (b) for the União da Vitoria station. 
power function. For the other stations JS, PV and FM this did not occur, as can be seen in Figure 7 for PV.

Note that the tail of the Lognormal distribution with respect to the minimums for the probability level 0.1 tends to a power function as a consequence of the Weibull distribution, for some of the stations. It is concluded that the Lognormal distribution can be considered the parent distribution for PA, UV, SC, SB, AV, $\mathrm{SM}, \mathrm{RN}$ and VL stations.

The moment diagram shown in Figure 8 was compiled with the series of normalized daily mean flows and the theoretical curve of the Weibull and Lognormal distributions. It is observed in this graph that the asymmetry of the series of daily average flows observed in the Iguaçu river is greater than the asymmetry of the Weibull distribution. It was also possible to demonstrate that the average daily flows better fit around the Lognormal distribution.

The dependence of the $k$ parameter of the Weibull distribution of the $V_{X}$ of the parent distribution (series of daily mean normalized flows) is shown in Figure 9, with $k$ originating from the series of modulated annual minimum flows. This graph shows a dispersion around the theoretical curve of the Lognormal distribution.

The $b$ parameter of the Weibull distribution depends on an effective number of repetitions $v$. Different values of $v$ were tested to visualize the difference in shape of the theoretical curves. For the series of normalized annual minimum flows, we have Figures 10, 11 and 12, with $v=10, v=20$ and $v=1$, respectively.

For $v=10$ and $v=20$ the result was similar considering the shape of the curves, but for $v=10$ the observed data fit better around the theoretical curve of the Lognormal distribution. When $v=l$ is considered the theoretical curves are not good, and it is worth noting that this value is questionable because it would represent a series of annual minimums.

The dependence of the $\mu$ parameter of the Weibull distribution, with the minimum annual flows normalized as a function of the respective $V_{X}$ of the daily mean flows, with $v=10$, of the Gamma and Lognormal distributions is shown in Figure 13. Again, there
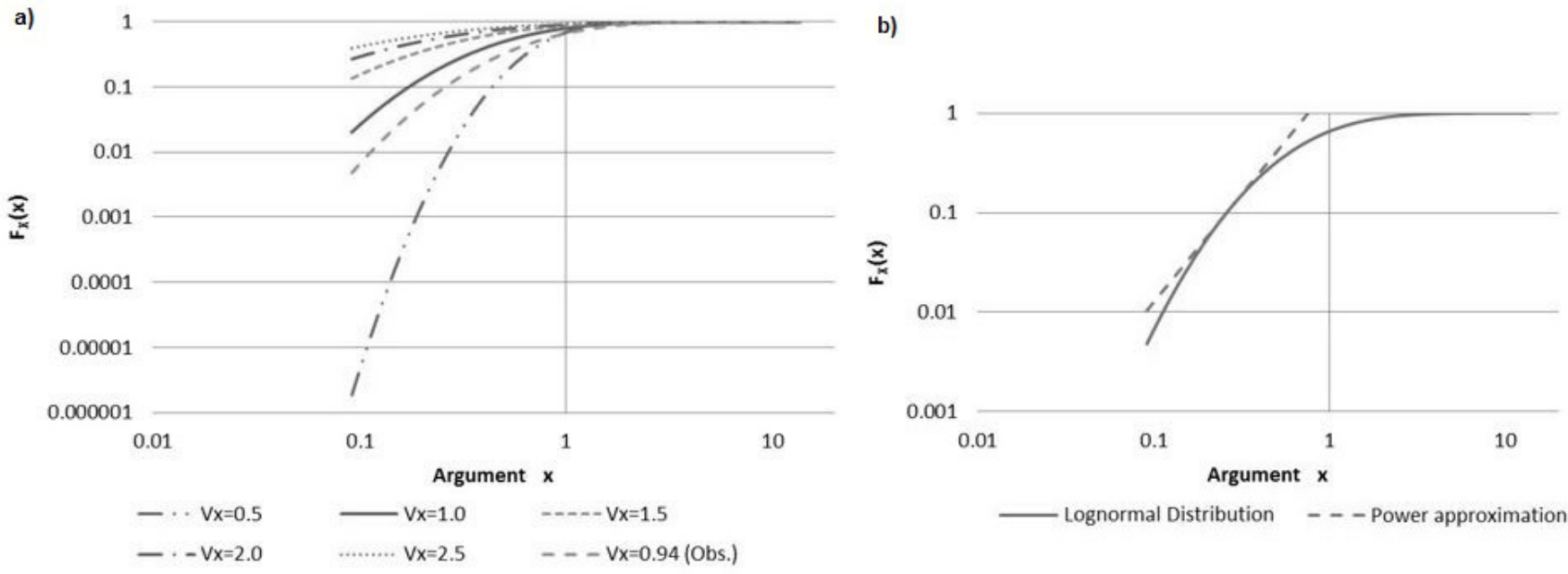

Figure 6. Lognormal distribution normalized in bilogarithmic scale for different values of $V_{X}$ (a) with the approximation of the power function (b) for the São Mateus do Sul station.
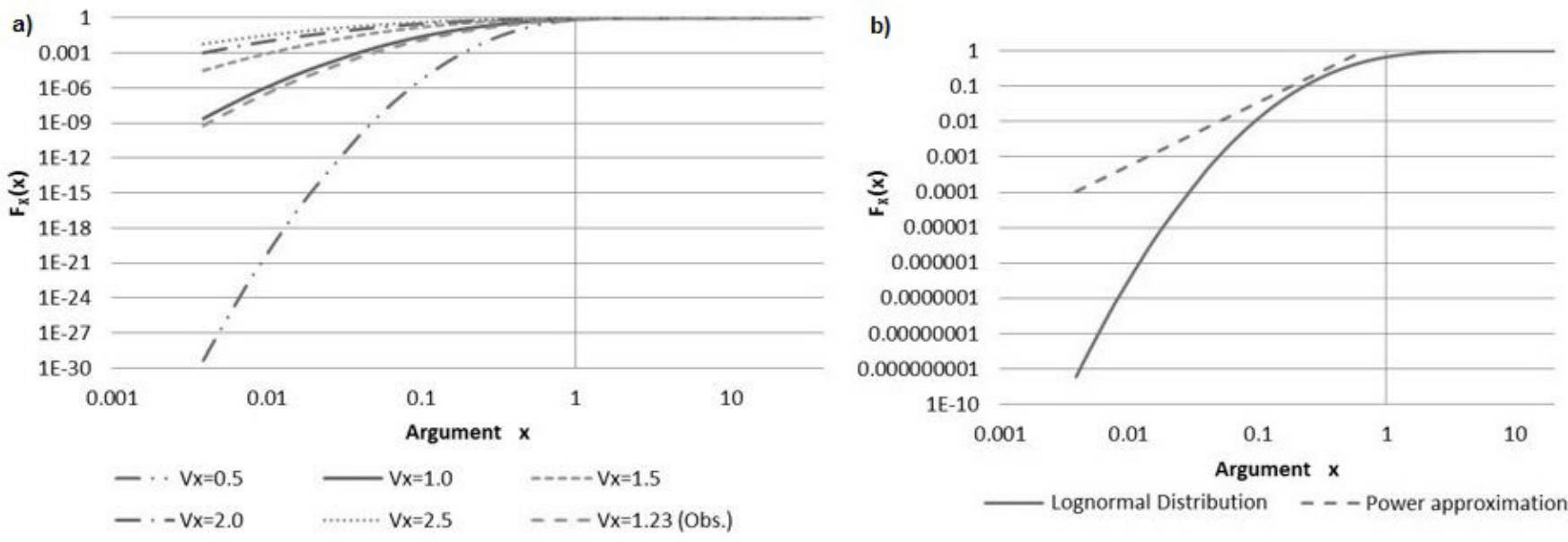

Figure 7. Lognormal distribution normalized in bilogarithmic scale for different values of $V_{X}$ (a) with the approximation of the power function (b) for the Ponte do Vitorino station. 


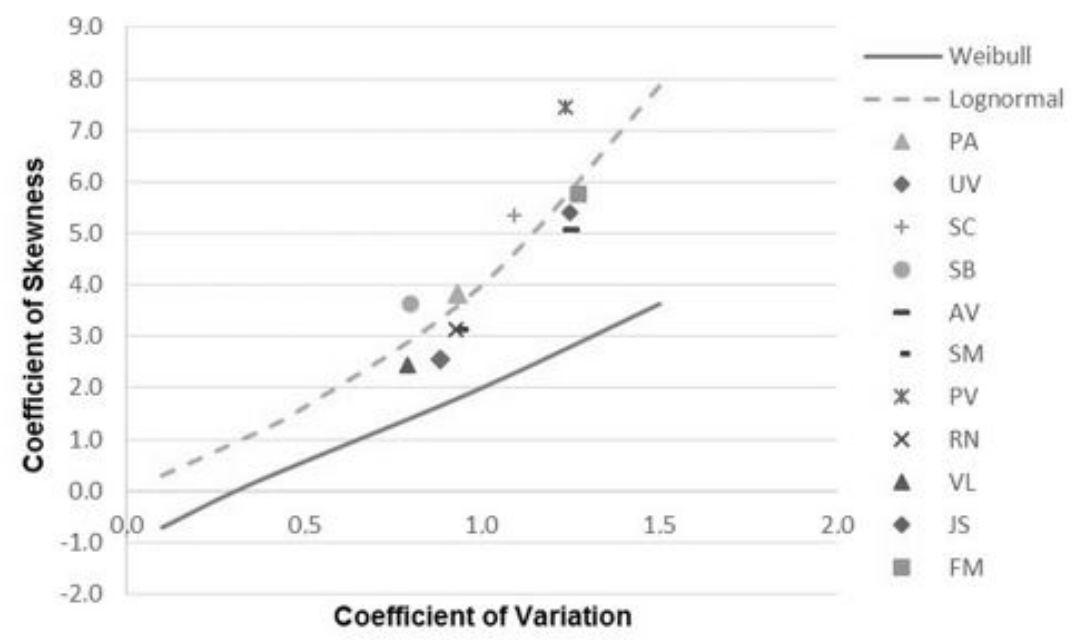

Figure 8. Moment diagram $\left(\gamma \times V_{X}\right)$ with the normalized daily mean flows and the theoretical curve of the Weibull and Lognormal distributions.

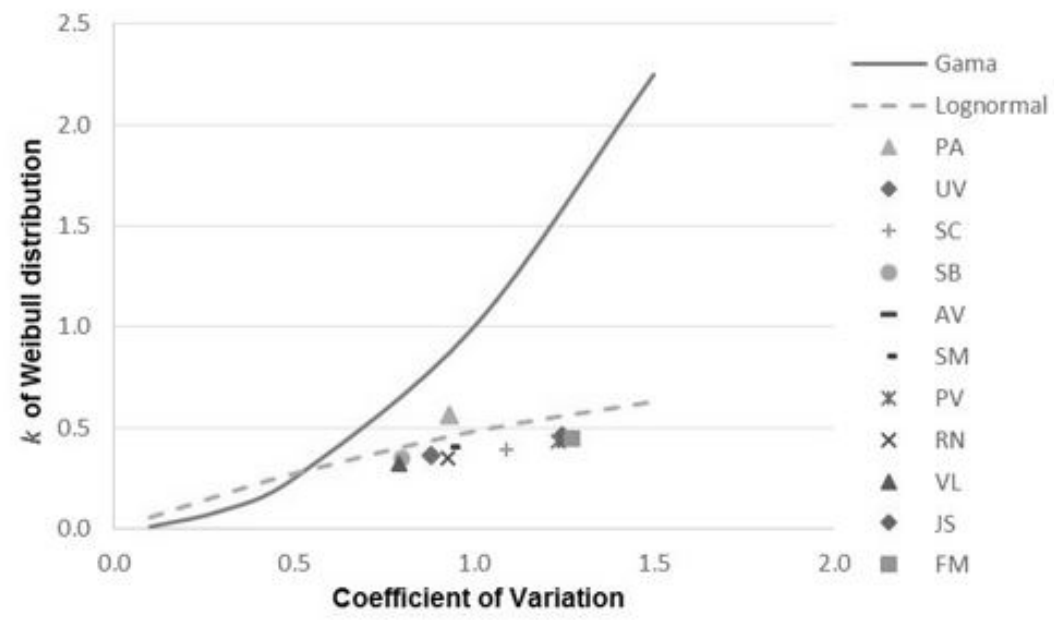

Figure 9. Dependence of the $\mathrm{k}$ parameter of the Weibull distribution, the series of normalized annual minimum flows, the coefficient of variation of the Gamma and Lognormal distributions.

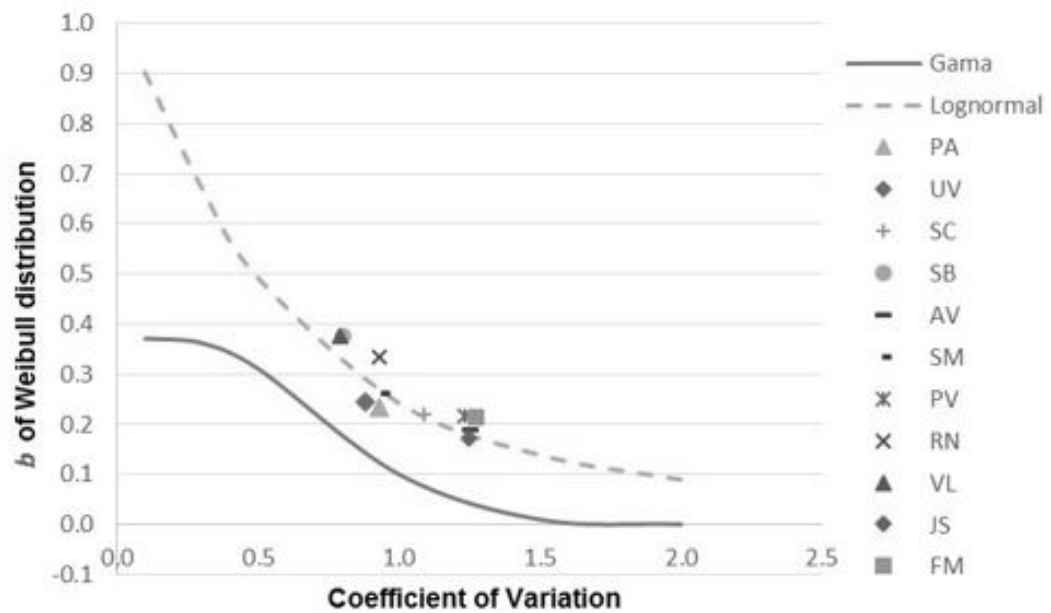

Figure 10. Dependence of the parameter b of the Weibull distribution, the series of normalized annual minimum flows, the coefficient of variation of the Gamma and Lognormal distributions, for $\boldsymbol{v}=10$. 


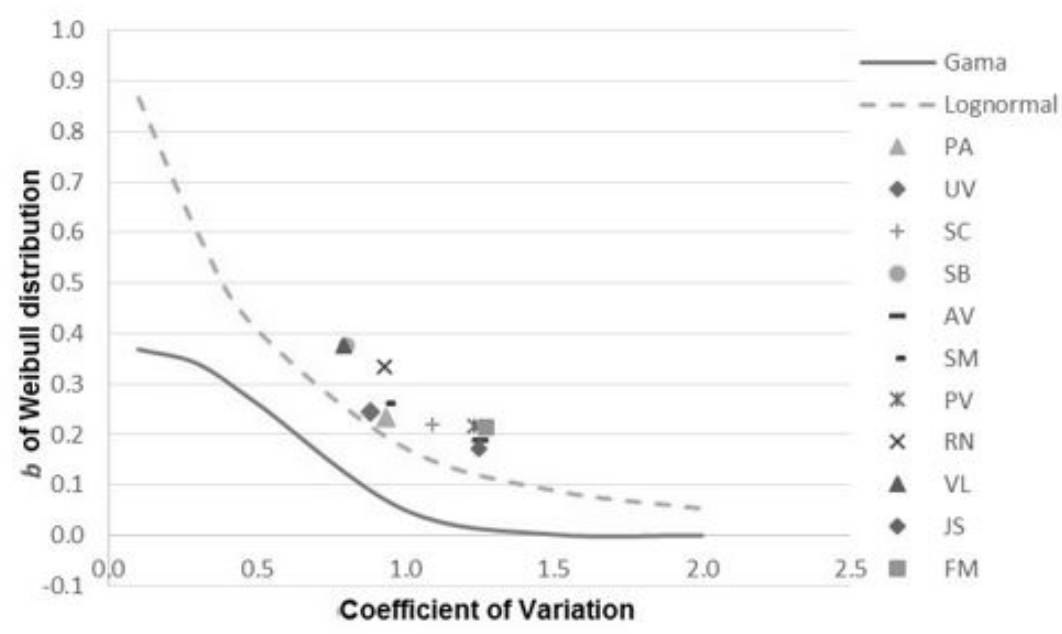

Figure 11. Dependence of the parameter b of the Weibull distribution, the series of normalized annual minimum flows, the coefficient of variation of the Gamma and Lognormal distributions, for $\boldsymbol{v}=20$.

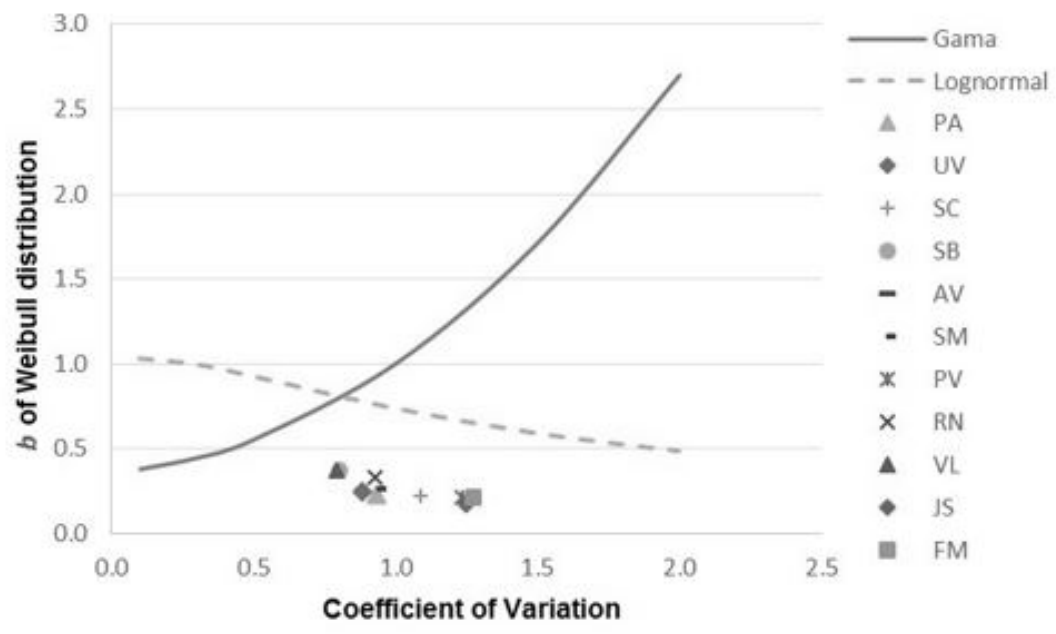

Figure 12. Dependence of the parameter b of the Weibull distribution, the series of normalized annual minimum flows, the coefficient of variation of the Gamma and Lognormal distributions, for $v=1$.

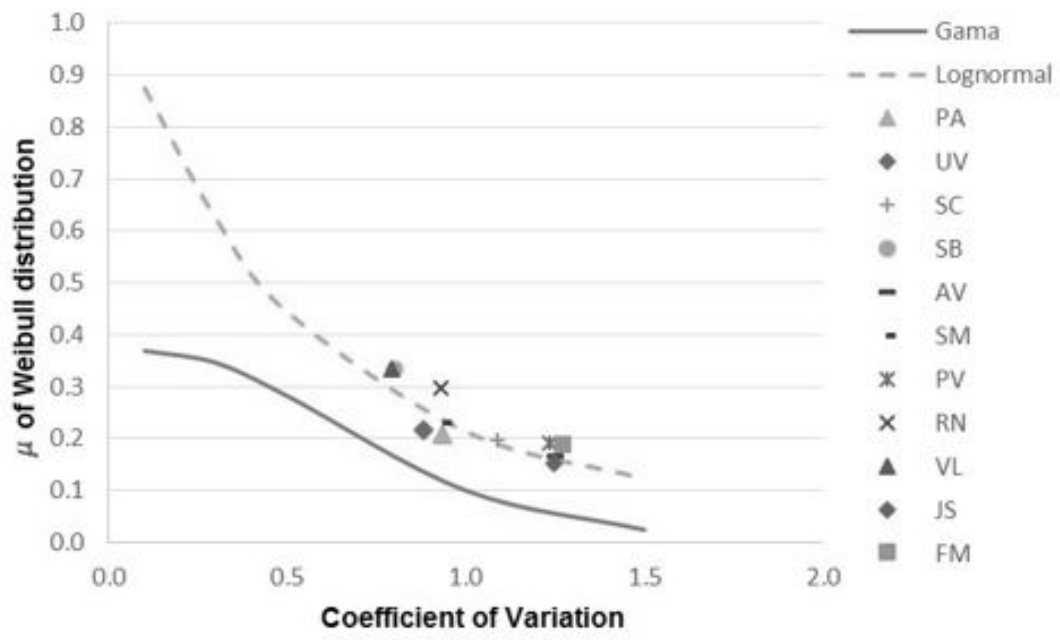

Figure 13. Dependence of the $\mu$ parameter of the Weibull distribution, with the normalized annual minimum flows, of the coefficient of variation of the Gamma and Lognormal distributions. 


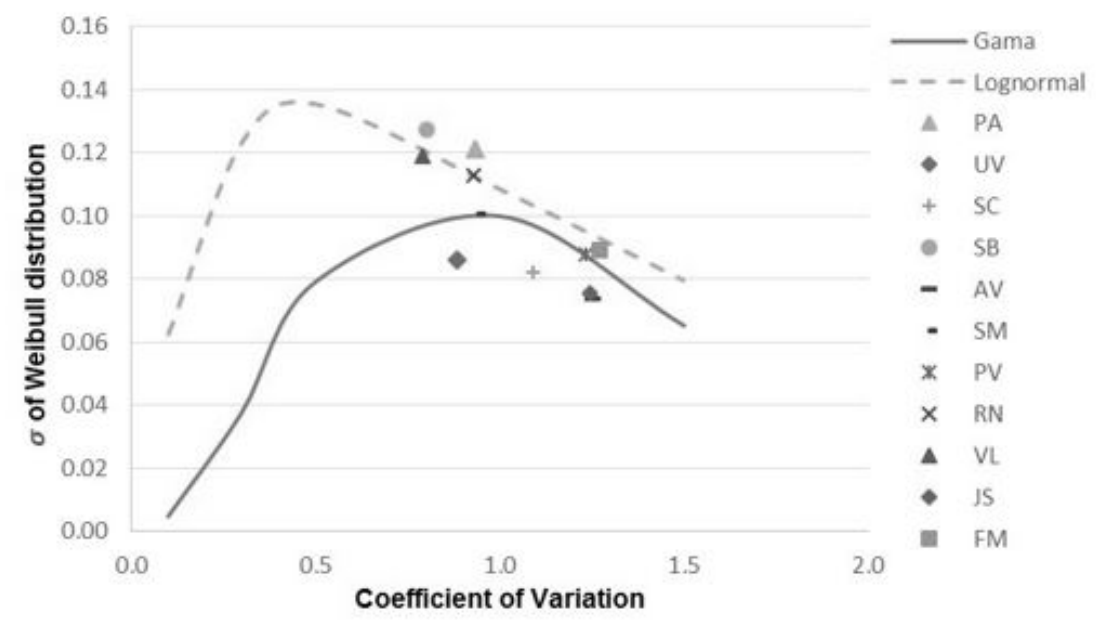

Figure 14. Dependence of the $\sigma$ parameter of the Weibull distribution, with the normalized annual minimum flows, of the coefficient of variation of the Gamma and Lognormal distributions.

is a dispersion of the sample points around the theoretical curve of the Lognormal distribution.

The parameters $k, b$ and $\mu_{X}$, of the normalized annual minimum flow series, fit the Lognormal distribution well.

Finally, Figure 14 shows that the standard deviation $\sigma$ of the normalized annual minimum flows as a function of the respective $V_{X}$, is distributed around the two distributions investigated. Note that the Lognormal distribution conforms to the sample data. Only Figure 14 does not allow us to reach this conclusion, because the points are dispersed around the two curves.

\section{CONCLUSION}

The main conclusions of this study are divided in terms of Conventional Analysis and Asymptotic Analysis.

\section{Conventional analysis}

The W2 distribution presented smaller flows than the LN2 distribution for the 10-year return period, for most of the stations analyzed, for both minimum moving average minimum flows of 7 days and minimum annual flows.

It was observed that the LN2 distribution approached more of the empirical distribution for a 10 -year return period for minimum moving averages of 7 days.

LN2 was the distribution that presented the best adjustment according to the $\chi^{2}$ test, in almost all the stations.

The KS test had a more conservative result, rejecting the $H_{0}$ hypothesis for most stations in the Iguaçu river basin. This is probably due to the fact of dividing the series into two, one part to estimate parameters and another to apply the test.

\section{Asymptotic analysis}

For the river basin of the Iguaçu River, it was possible to verify that the distribution Gama is the parent distribution that most closely approximates the power function of the attractiveness domain of the Weibull distribution.
The graphs confirmed the near-zero power law behavior of this distribution. For coefficients of variation less than 0.5 , the power behavior occurs only for very small probabilities, while for larger values the approximation is valid for higher probabilities.

For the probability level 0.1 the hypothesis that the lower tail of the Lognormal distribution tends to the power function was confirmed for some of the stations studied.

The LN2 distribution did not present a good approximation to the power function of the Weibull distribution, for three of the stations of the Iguaçu river basin. This is not enough to reject it as a good candidate to model minimum flows, due to the subsequent analysis of the parameters.

It was observed that the asymmetry of the series of daily average flows of the stations in the Iguaçu river basin is greater than the asymmetry of the Weibull distribution, and has a good fit to the Lognormal distribution.

Considering these results, it can be said that the parent Lognormal distribution can be recommended for the study of minimum flows for some of the stations of the Iguaçu river basin.

However, it is recommended that future studies of the frequency of minimum flows in other river basins should contemplate the investigation of the theoretical distribution that best fits the local data. For this investigation, according to the literature and the results of the present study, the three distributions used, Weibull, Lognormal of two parameters and Gamma can be recommended for this analysis.

According to the studies of the conventional analysis it is preferred to indicate the LN2 rather than the W2 for studies of minimum flows in the basin of the Iguaçu river.

\section{ACKNOWLEDGEMENTS}

To CAPES for the scholarship granted to the first author.

\section{REFERENCES}

ANA - AGÊNCIA NACIONAL DE ÁGUAS. HidroWeb: sistemas de informações hidrológicas. Brasília, 2014. Available from: <http://hidroweb.ana.gov.br/>. Access on: 30 aug. 2014. 
BANGASH, R. F.; PASSUELLO, A.; HAMMOND, M.; SCHUHMACHER, M. Water allocation assessment in low flow river under data scarce conditions: a study of hydrological simulation in Mediterranean basin. The Science of the Total Environment, v. 440, p. 60-71, 2012. http://dx.doi.org/10.1016/j.scitotenv.2012.08.031. PMid:22939610.

CLARKE, R. T. Hidrologia estatística. In: TUCCI, C. E. M. Hidrologia ciência e aplicação. Porto Alegre: Editora da UFRGS, 1993. (Livro da Coleção ABRH).

COLES, S. An introduction to statistical modeling of extreme values. London: Springer, 2001. http:/ /dx.doi.org/10.1007/978-1-4471-3675-0.

CORREA, S. W.; MELO, C. R. Análise estatística de precipitações máximas diárias anuais e vazões mínimas anuais na sub-bacia Paraopeba, rio Ribeirão da Ajuda. In: CONGRESSO BRASILEIRO DE ENGENHARIA AGRÍCOLA (CONBEA), 42., 2014, Campo Grande. Anais... Campo Grande: CONBEA, 2014.

EUCLYDES, H. P. Regionalização de vazões máximas e minimas para a bacia do rio Juatuba-MG. 1992. 66 f. Dissertação (Mestrado) Universidade Federal de Viçosa, Viçosa, 1992.

FINKLER, N. R.; MENDES, L. A.; SCHNEIDER, E. H. M.; BORTOLIN, T. A.; SCHNEIDER, V. E. Análise de funções de distribuição de probabilidades na determinação de vazão mínima sazonal. In: SIMPÓSIO BRASILEIRO DE RECURSOS HÍDRICOS, 21., 2015, Brasília. Anais... Brasília: SBRH, 2015.

GOMIDE, F. L. S. Noções de estatística e probabilidade (apêndice). In: PINTO, N. L. S.; HOLTZ, A. C. T.; MARTINS, J. A.; GOMIDE, F. L. S. Hidrologia básica. São Paulo: Edgard Blücher, 1976.

GOTTSCHALK, L.; YU, K.; LEBLOIS, E.; XIONG, L. Statistics of low flow: theoretical derivation of the distribution of minimum streamflow series. Journal of Hydrology, v. 481, p. 204-219, 2013. http://dx.doi.org/10.1016/j.jhydrol.2012.12.047.

KAVISKI, E. Vazões de estiagem em pequenas bacias hidrográficas do Estado de Santa Catarina. In: SIMPÓSIO BRASILEIRO DE HIDROLOGIA E RECURSOS HÍDRICOS, 1983, Florianópolis. Anais... Florianópolis: ABRH, 1983. p. 43-67.

MAMUN, A. A.; HASHIM, A.; DAOUD, J. I. Regionalisation of low frequency curves for the Peninsular Malaysia. Journal of Hydrology, v. 381, n. 1-2, p. 174-180, 2010. http://dx.doi.org/10.1016/j. jhydrol.2009.11.039.

MELLO, C. R.; VIOLA, M. R.; BESKOW, S. Vazões máximas e mínimas para bacias hidrográficas da região Alto Rio Grande, MG. Ciência e Agrotecnologia, v. 34, n. 2, p. 494-502, 2010. http:// dx.doi.org/10.1590/S1413-70542010000200031.

MOREIRA, M. C.; SILVA, D. D. Análise de métodos para estimativa das vazões da Bacia do Rio Paraopeba. Revista Brasileira de Recursos Hídricos, v. 19, n. 2, p. 313-324, 2014. http://dx.doi.org/10.21168/ rbrh.v19n2.p313-324.
NAGHETTINI, M.; PINTO, E. J. A. Hidrologia estatística. Belo Horizonte: CPRM, 2007.

NAGHETTINI, M.; VON SPERLING, M. Características hidrológicas de rios. In: VON SPERLING, M. Estudos e modelagem da qualidade da água de rios. Belo Horizonte: Editora UFMG, 2014. p. 59-96.

NAKAYAMA, P. T.; MENDES, J. B.; PILAN, S. B. Avaliação da estiagem no período chuvoso de 2013/2014 na região do sistema Cantareira. In: SIMPÓSIO BRASILEIRO DE RECURSOS HÍDRICOS, 21., 2015, Brasília. Anais... Brasília: SBRH, 2015.

SILVA, A. M.; OLIVEIRA, P. M.; MELLO, C. E.; PIERANGELI, C. Vazões mínimas e de referência para outorga na região do Alto Rio Grande, Minas Gerais. Revista Brasileira de Engenharia Agrícola e Ambiental, v. 10, n. 2, p. 374-380, 2006. http://dx.doi.org/10.1590/ S1415-43662006000200019.

SILVA, C. L. Análise estatística das características de vazão do córrego Capetinga. Revista Brasileira de Engenharia Agrícola e Ambiental, v. 7, n. 2, p. 311-317, 2003. http://dx.doi.org/10.1590/ S1415-43662003000200021.

SILVINO, A. N. O.; SILVEIRA, A.; MUSIS, C. R.; WYREPKOWSKI, C. C. Determinação de vazões extremas para diversos períodos de retorno para o Rio Paraguai utilizando métodos estatísticos. Geociências, v. 26, n. 4, p. 369-378, 2007.

SMAKHTIN, V. U. Low flow hydrology: a review. Journal of Hydrology, v. 240, n. 3-4, p. 147-186, 2001. http://dx.doi.org/10.1016/ S0022-1694(00)00340-1.

STEDINGER, J. R.; VOGEL, R. M.; FOUFOULA-GEORGIOU, E. Frequency analysis of extreme events. In: MAIDMENT, D. R. Handbook of bydrology. New York: McGraw-Hill, 1992. p. 18.1-18.66.

TOMAZ, P. Vaðão mínima com Weibull. [S.1.: s.n.], 2013. cap. 133. Apostila do Curso de Manejo de águas pluviais.

ULIANA, E. M.; MARTINS, C. A. S.; SILVA, J. G. F.; REIS, E. F. Análise estatística para determinação da Q7,10 na bacia do rio São Mateus-ES. In: ENCONTRO LATINO AMERICANO DE INICIAÇÃO CIENTÍFICA, 15.; ENCONTRO LATINO AMERICANO DE PÓS-GRADUAÇÃO, 11., 2011, São José dos Campos. Anais... São José dos Campos: Universidade do Vale do Paraíba, 2011.

VICTORINO, E. C.; MATIAS, G. C.; DA, T. B. S.; SILVA, R. C. P. A.; DE CARVALHO, L. G. Adequabilidade de diferentes distribuições de probabilidade aplicadas a uma série histórica de vazões mínimas para o rio Grande, na região de Barreiras (BA). In: CONGRESSO BRASILEIRO DE ENGENHARIA AGRÍCOLA (CONBEA), 42., 2014, Campo Grande. Anais... Campo Grande: CONBEA, 2014. 


\section{Authors contributions}

Adelita Ramaiana Bennemann Granemann: Contributed in the conception of the work, literature review, data acquisition, treatment and analysis, map elaboration, discussion of results, writing, formatting and review of the article.
Miriam Rita Moro Mine: Contributed to the conception of the work, literature review, data analysis, discussion of results, writing, formatting and review of the article.

Eloy Kaviski: Contributed to literature review, data treatment and analysis, discussion of results, writing, formatting and article revision. 